EDITORIAL

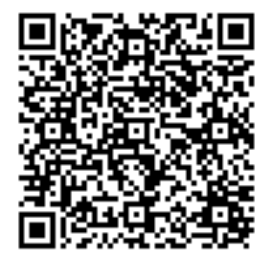

\title{
Message from the Editor-in-Chief of International Journal of Science Annals, Vol. 4, No. 1, 2021
}

\author{
Melnyk Yu. B. ${ }^{1,2}$ (D) \\ ${ }^{I}$ Kharkiv Regional Public Organization "Culture of Health" (KRPOCH), Ukraine \\ ${ }^{2}$ Scientific Research Institute KRPOCH, Ukraine
}

Received: 17.02.2021; Accepted: 17.03.2021; Published: 30.06 .2021

\begin{tabular}{|c|c|}
\hline $\begin{array}{l}\text { Keywords: } \\
\text { Copyright: }\end{array}$ & $\begin{array}{l}\text { International, Journal, Website, Modernization, Integration, KRPOCH Publishing } \\
\text { (C) } 2021 \text { Melnyk Yu. B. Published by Archives of International Journal of Science } \\
\text { Annals }\end{array}$ \\
\hline DOI & https://doi.org/10.26697/ijsa.2021.1.1 \\
\hline Conflict of interests: & The author declares that there is no conflict of interests \\
\hline Source of support: & This research did not receive any outside funding or support \\
\hline $\begin{array}{r}\text { Information about } \\
\text { the author: }\end{array}$ & $\begin{array}{l}\text { Melnyk Yuriy Borysovych }- \text { https://orcid.org/0000-0002-8527-4638; } \\
\text { YBM.office@gmail.com; Doctor of Philosophy in Pedagogy, Associate Professor; } \\
\text { Founder and Chairman of the Board, Kharkiv Regional Public Organization } \\
\text { "Culture of Health”; Director, Scientific Research Institute KRPOCH; Kharkiv, } \\
\text { Ukraine. }\end{array}$ \\
\hline
\end{tabular}

\section{Dear Readers and Authors,}

It is a great honor for us to publish the International Journal of Science Annals (IJSA) for the fourth year in a row.

IJSA is an academic periodical peer-reviewed indexed Journal that provides a scientific platform for presenting and discussing new trends and issues in Social and Behavioral Sciences.

IJSA mission: international cooperation of scientists conducting research in the field of integration of human sciences and health.

IJSA Editorial Board includes the most authoritative scientists from 17 countries, 5 continents in the fields of Education, Psychology, Medicine.

For 3.5 years of its existence, the IJSA is presented in more than 35 international scientometric databases, repositories and search engines, such as Crossref System, Google Scholar, OAJI (USA); ISSN, ROAD (France); COPE, EndNote, OpenDOAR, CORE, Jisc (UK); DOAJ, Scilit (Switzerland); Publons (New Zealand); ERIH PLUS, OpenAIRE (Norway); BASE, ResearchGate, ASI (Germany); MIAR (Spain); Index Copernicus International (Poland); DRJI (India); RSCI (Russia); OUCI, National Library of Ukraine (Ukraine), etc.

It is a great honor and responsibility for the IJSA to become a full member of the Committee of Publication Ethics (COPE) (https://is.gd/COPE_IJSA).

The IJSA is indexed in: ICI ICV 91.27; ICDS 3.5; CGIJ OAJI 0.251

There were some technical changes at the beginning of 2021, of which we would like to inform the Readers and Authors of the IJSA.

\section{Modernization of the IJSA Website}

The current development of IT technologies allowed to update the IJSA website (https://ijsa.culturehealth.org). Since 2018, the IJSA has used the "Academic Journal Site Model" developed by me (Melnyk, 2018), which consisted of the following structural elements:

Section 1 "Home" included subsections (https-pages): "Journal Info"; "From the Editorial Office"; "Databases, Indexing";

Section 2 "Editorial Board" included subsections (httpspages): "Editorial Board", "Reviewers", "Editing and Reviewing Process".

Section 3 "Editorial Policies" included subsections (https-pages): "Editorial Policies", "Plagiarism Policy", "Open Access Policy", "The Ethics Codex of Scientific Publications", "Disclaimer", "License Terms", "Terms of Publications (Fee)".

Section 4 "Archive" included subsections (https-pages): "Previous Issues", "Current Issue", "Articles Online First".

Section 5 "Instructions for Authors" included subsections (https-pages): "General Requirements", "Manuscript Templates", "Supplemental Materials".

Section 6 "Statistics" included subsections (https-pages): "Publications", "Authors", "Readers".

Section 7 "Contact" included subsections (https-pages): "Contact", "Quick Contact", "Subscriptions".

Updated the content of some pages of subsections and documents, among them: Editor and Reviewer Certificates samples, Reviewer Evaluation Form, Template for the Replies to Reviewers' Comments, etc. 
The manuscript templates for all types of publications in the Journal have been updated with detailed instructions for filling out.

For the convenience of Authors in the new interface of the website, the button "Online Submission System" has been added, which allows them to upload manuscripts via the mail server of the website.

The emblems of the Institute, the Publishing and the Repository of the KRPOCH have also been added, which have hyperlinks to relevant websites.

A new position "Keywords Bank" has been created, which makes it possible to quickly search for papers in the Journal by keywords.

In addition, the website is equipped with a search engine for information among all the content of the website.

The website content is presented in English and Ukrainian.

\section{Integration the IJSA Website with the Repository of the KRPOCH Publishing Website \\ The IJSA website is integrated with the Repository of the KRPOCH Publishing website (https://ekrpoch.culturehealth.org/handle/lib/71) based on the DSpace platform. \\ This ensured greater integration of the IJSA papers with the global informational scientific space. \\ The IJSA adheres to the principles of open access and supports a greater global exchange of knowledge. The Creative Commons Attribution License (CC BY 4.0) applies to all papers.}

\section{Crossmark Registration has been Introduced for All Papers in the IJSA}

A standardized Crossmark button in all IJSA papers allows you to see the status of a content item and look through any additional paper metadata of your choice. The Crossmark button is part of the paper in PDF format, which allows you to inform readers about any changes made to the paper, regardless of the time of its publication on the IJSA website.

\section{Updated Paper Design in the IJSA}

The design of title pages of papers has been changed and improved. From now on, the title page of a paper has: the paper title, authors' names, their institutional belonging and country, the paper history, abstract (structured by the paper elements), Keywords, Copyright, DOI and UDC, information about Conflict of Interests, Peer Review, Source of Support, detailed information about the Authors, and also added Crossmark button.

Each IJSA page has the Journal's title in the footers, as well as the volume and issue numbers, print ISSN: 2617 2682; online ISSN: 2707-3637; DOI: 10.26697/ijsa, as well as the logo image of the Journal.

At the end of the paper, there is information on how to cite this paper.

Information about the archives where the paper is available, as well as icons of the Creative Commons Attribution License (CC BY 4.0) used by the KRPOCH Publishing to publish papers in the IJSA with the appropriate hyperlink to the terms of this license are indicated.

\section{Changes in the Format of Scientific Papers in the IJSA}

Due to the new trends, including regarding the references format (APA Style $\left(7^{\text {th }}\right.$ ed.), the requirements for paper format have been changed.

You can read about the changes both in the online version on the IJSA website and in the printed version at the end of the current issue.

We thank all the Authors and Readers of the IJSA and look forward to further cooperation.

Take care and stay healthy!

\section{References}

Melnyk, Yu. B. (2018). Academic Journal Site Model. https://doi.org/10.26697/Preprint.Melnyk.1.2018

\section{Dr. Yuriy Melnyk, \\ Director of KRPOCH Publishing, Editor-in-Chief of the IJSA.}

\section{Cite this article as:}

Melnyk, Yu. B. (2021). Message from the Editor-in-Chief of International Journal of Science Annals, Vol. 4, No. 1, 2021. International Journal of Science Annals, 4(1), 5-6. https://doi.org/10.26697/ijsa.2021.1.1

The electronic version of this article is complete. It can be found online in the
https://ijsa.culturehealth.org/en/arhiv Archive
and $\begin{gathered}\text { in } \\ \text { the }\end{gathered}$ KRPOCH
https://ekrpoch.culturehealth.org/handle/lib/71 